\title{
越後平野の沖積層形成における火山性洪水イベントの影響
}

Influence of a volcanogenic flood event on an alluvial depositional system: the Holocene Echigo Plain of northeast Japan

\section{卜部厚志 ${ }^{*}$ 藤本裕介 ${ }^{* *,}$ 片岡香子*}

\section{Atsushi Urabe*, Yusuke Fujimoto**, and Kyoko S. Kataoka*}

\section{0 年 10 月 26 日受付.}

2011 年 6 月 25 日受理. 新潟大学災害・復興科学研究所

Research Institute for Natural Hazards and Disaster Recovery, Niigata University, Ikarashi 2-cho 8050, Niigata 950-2181, Japan

** 新潟大学理学部地質科学科

Department of Geology, Faculty of Science, Niigata University, Ikarashi 2-cho 8050, Niigata 950-2181, Japan

\section{株式会社}

Present address: East Japan Railway Company

Corresponding author; A. Urabe, urabe@gs.niigata-u.ac.jp

\begin{abstract}
The Echigo Plain, which faces the Sea of Japan in northeast Japan, is a typical coastal plain with numerous sand dunes. We examined the sedimentology of pumiceous sediments (lahar deposits) in the Agano River area of the Echigo Plain, derived mainly from a largescale dam-break flood after the Numazawako eruption (about 5 ka), using an existing borehole dataset and facies analysis of sediment cores.

The lahar deposits show different sedimentary facies in coastal areas versus the shallow marine environment. Coarse-grained pumiceous sediments (5-8 $\mathrm{m}$ thick) are interpreted to have been deposited under the delta front or in a delta plain environment in a coastal area. Sandy silt deposits (pro-delta facies), including pyroclastic material (horizons of concentrated volcanic glass shards and heavy minerals), are distributed in the shallow sea area.

The large volumes of volcaniclastic sediment delivered during the flood event induced the rapid progradation of the delta system in the Agano River region. The deposition of volcaniclastic sediments in the shallow sea also caused progradation of the delta system and changed the coastal landforms along the margin of the Echigo Plain.

The flood event resulted in an increase in the progradation rate of the depositional system from 0.9 to $2.5 \mathrm{~km}$ per 1000 years. An understanding of large-scale pyroclastic resedimentation can contribute to evaluating and predicting the volume of sediment discharge and the nature of hazards created by a volcanogenic flood and its aftermath in an alluvial plain setting.
\end{abstract}

Keywords: Numazawa volcano, ignimbrite dam, pyroclastic resedimentation, Echigo Plain, delta progradation, Holocene

\section{はじめに}

越後平野は，信濃川と阿賀野川の下流域に位置し，分布や 弧状の形態の相違から新砂丘 I から新砂丘IIIに大分される砂 丘列群が発達する（新潟古砂丘グループ, 1974, 1979; 田中 ほか, 1996 など : Figs. 1, 2). 越後平野の沖積層の堆積過 程は, 2 つの河川流域において異なり, 新潟市西部の信濃川 流域（西蒲原地域）では, 約 8,000 年前にバリアー・ラグー ンシステムが形成されたのち, 急激な沈降による堆積システ ムの後退と前進を繰り返しながら, 全般的にはバリアー・ラ グーンシステムが前進して平野を埋積している（ト部ほか, 2006a)。一方，新潟市東部の阿賀野川流域では，河川によ る粗粒砕屑物の供給によって最終水期最盛期以降の海進期か ら河川起源の堆積物が分布し, 海進のピーク時以降もバリ アーシステムは形成されず，新砂丘 I から新砂丘而の砂丘列 はデルタシステムを基礎としていることが明らかとなってい る（卜部, 2008)。このように, 越後平野は, 海岸部に砂丘
が発達する地形環境でありながら卓越する営力の違いによつ て 2 つ異なる堆積システムを有しながら発達する. しか し，それぞれの堆積システムの前進要因について，特に，砂 丘列群が前方へシフト（堆積システムが急に前進）する要因 については明らかにされていない.

一般に海岸平野の沖積層は, 水河性海水準変動に加えて, 構造運動や堆積物供給のバランスによって形成されたものと 考えられる. このうち構造運動について, 越後平野は沖積層 の最大層厚が約 $150 \mathrm{~m}$ であることから, 沈降運動の影響を 大きく受けて形成されたものであると考えられている（鴨井 ほか, 2002; 卜部ほか, 2006a など). しかし, 堆積物の供給 は, 相対的海水準変動による堆積空間の確保や堆積システム の発達による堆積物のトラップなどの影響が考えられ, 堆積 システムの前進や後退を堆積物供給量の変化として見積もる ことは難しい. この課題に対して，大規模な土砂運搬イベン トを起源として沖積平野に堆積物が過剰に供給された場合の 堆積作用や堆積システムの変化から, 沖積層形成における堆 


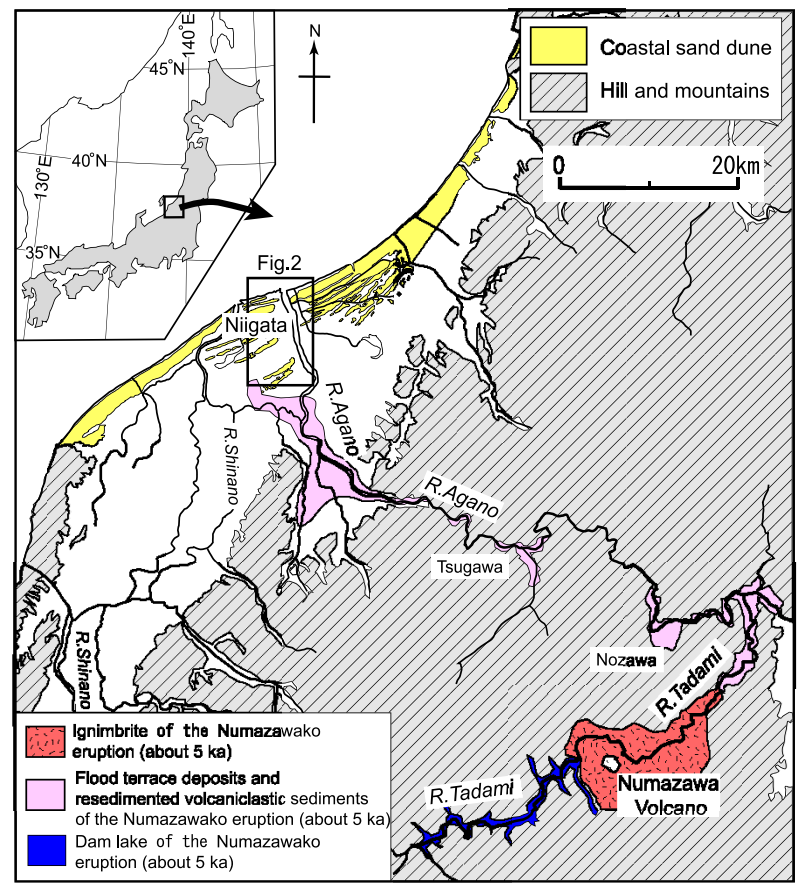

Fig. 1. Index map showing the location of the Numazawa Volcano upon the Echigo Plain.

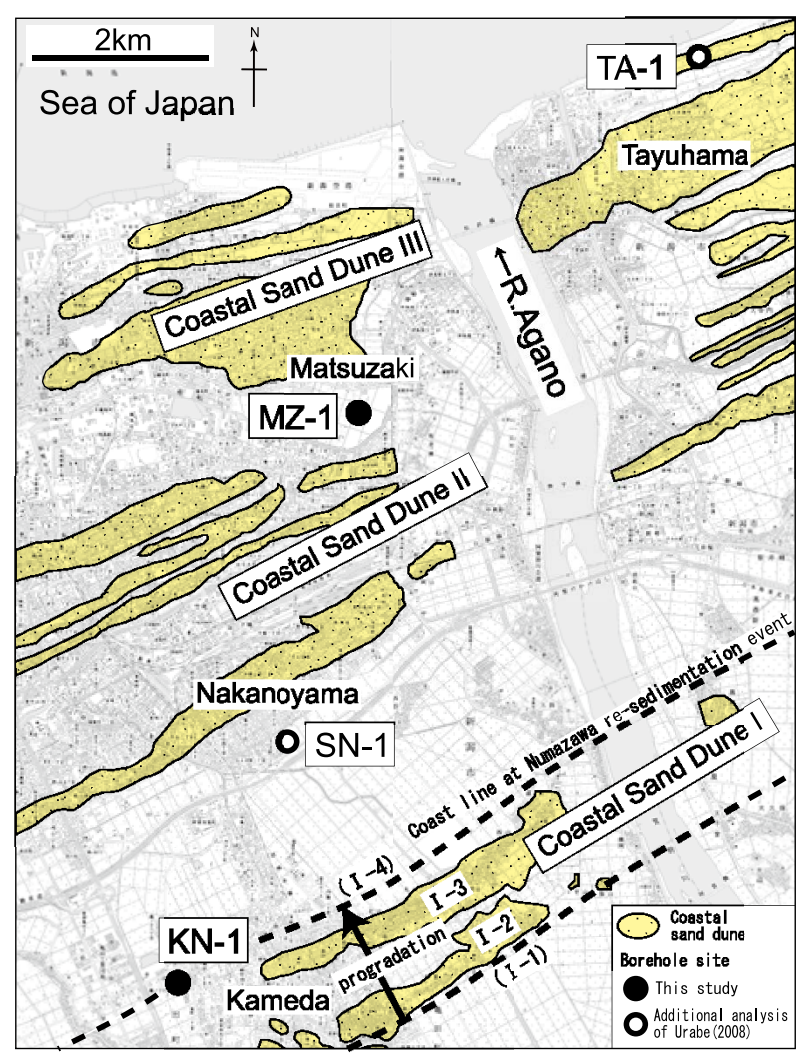

Fig. 2. Location map of the KN-1, SN-1, MZ-1 and TA-1 cores, also showing the distribution of coastal sand dunes. I-1 to I-4: subdivisions of coastal sand dune I.
積物の供給と堆積の関係を明らかにできる可能性がある.

越後平野に対する大規模な土砂供給イベントとして，沼沢 火山の活動があげられる. 福島県只見川中流域に位置する沼 沢火山は，約 5,350 年前に火砕流噴火（沼沢湖噴火）によ り只見川を一時的に堰き止め，ダム湖が決壊し大規模洪水流 が只見川・阿賀野川を約 $150 \mathrm{~km}$ にわたり流下したことが 明らかになっている (Kataoka et al., 2008, 2009). これ までの越後平野の検討からも新砂丘 I-4 以降の砂丘列での 軽石の混入 (坂井, 1980; 田中ほか, 1996 など) やボーリン グ試料によって, 砂層中に沼沢火山起源の軽石が濃集してい ることが認められている（ト部・片岡, 2005; 鴨井ほか 2006; 片岡ほか, 2006). しかし, 越後平野の沖積層におけ る大規模洪水流による砂層の分布や堆積システムに与えた影 響について不明な点が残されていた.

そこで, 本研究では越後平野の阿賀野川沿いにおいて採集 されたボーリングコア試料を用いて，各ボーリングコア試料 における堆積相と粒度分布, 鉱物組成, 重鉱物組成, 火山ガ ラスの形態について分析し, 沼沢火山起源の二次堆積物の認 定や二次堆積作用の影響の開始・終焉時期, 堆積システムへ の影響（砂丘列の前進）について明らかにした. また，二次 堆積した火砕物の層序対比（鍵層としての対比）の問題につ いて指摘する. なお, ここでは, ダム湖の決壊に起因した大 規模洪水流による堆積物を中心に扱うものとする.

\section{沼沢火山の噴火活動と二次堆積作用の概要}

福島県只見川流域に位置する沼沢火山（Fig. 1）は，直径 $2 \mathrm{~km}$ 程度の小型のカルデラを有する火山で, 約 5,350 年前 （cal BP）に火砕流噴火（沼沢湖噴火）を起こしている（山 元, 1995, 2003; 沼沢団体研究グループ, 1999; 山元・駒沢, 2004）。沼沢湖噴火は, 火砕流噴火 $\rightarrow$ プリニアン噴火 $\rightarrow$ マグ マ水蒸気爆発 $\rightarrow$ プニアン噴火の 4 つの噴火ステージから なる (山元, 1995, 2003). 最初の火砕流噴火は, 最も規模 が大きく谷埋めタイプの塊状軽石流相により, カルデラ周辺 の只見川とその支流の谷地形を埋積し, 只見川に貯水量約 $1.7 \mathrm{~km}^{3}$ と推定されるダム湖を形成した. このダムは只見川 の流入量を現在と同じとした場合約 40～200 日後に決壊し， 決壊による洪水ピーク流量は約 $30,000 \sim 50,000 \mathrm{~m}^{3} / \mathrm{s}$ 以上 と推定されている（Kataoka et al., 2008). また, 沼沢火 山より下流の只見川流域（約 $35 \mathrm{~km}$ ） と只見川合流部から 約 $20 \mathrm{~km}$ 下流までの阿賀川流域では, 土石流堆積物やハイ パーコンセントレイティッド流堆積物による比高 $20 \mathrm{~m}$ 以上 の堆積性の段丘を形成し, 洪水由来の堆積物は噴出源から約 $150 \mathrm{~km}$ 下流の越後平野にまで到達する（Kataoka et al., 2008, 2009). これらの堆積物は, 只見川や阿賀野川流域の 河成段丘では, 軽石片を多く含む火山灰や火山灰質砂層とし て認定でき，構成粒子としては自形の角閃石や扁平型 $(\mathrm{Hb})$ ・ 中間型 $(\mathrm{Ca}, \mathrm{Cb})$ の火山ガラス（吉川, 1976）を多く含む ことで特徵づけられる.

\section{コア試料の掘削と分析方法}

本研究では, 新潟市内の阿賀野川沿いの 2 箇所において 
Table 1. Calibrated ${ }^{14} \mathrm{C}$ ages of wood, peaty sediment, peaty fragments, and shells from the cores. All samples were analyzed at the Institute of Accelerator Analysis Limited, Kawasaki, Japan. Age data of the KN-1, SN-1, MZ-1, and TA-1 cores were recalculated using Calib 6.0.1 (Stuiver and Reimer, 1993). The calibration database was sourced from Intcal 09 and Marine 09 (Reimer et al., 2009). Corrections for the ages of shell samples assumed $\Delta \mathrm{R}=133$, where the $\Delta \mathrm{R}$ uncertainty $=$ 41.

\begin{tabular}{|c|c|c|c|c|c|c|c|c|c|c|c|}
\hline $\begin{array}{l}\text { Core } \\
\text { No. }\end{array}$ & $\begin{array}{l}\text { Depth in } \\
\text { core }(m)\end{array}$ & $\begin{array}{l}\text { Elevation } \\
(\mathrm{m})\end{array}$ & Material & Method & $\begin{array}{l}\delta^{13} \mathrm{C} \\
(\% 0)\end{array}$ & $\begin{array}{l}\text { Measured }{ }^{14} \mathrm{C} \\
\text { age (yrs BP) }\end{array}$ & $\begin{array}{c}\text { Conventional } \\
{ }^{14} \mathrm{C} \text { age (yrs BP) }\end{array}$ & $\begin{array}{c}\text { Calibrated }{ }^{14} \mathrm{C} \text { age } \\
(2 \sigma)(\text { cal BP) }\end{array}$ & Sample code & $\begin{array}{c}\text { Calibration } \\
\text { database }\end{array}$ & Reference \\
\hline TA-1 & 12.78 & -8.78 & $\begin{array}{c}\text { peaty } \\
\text { sediment }\end{array}$ & AMS & -26.47 & $270 \pm 30$ & $250 \pm 30$ & $325-270$ & IAAA-81003 & IntCal09 & This study \\
\hline TA-1 & 24.55 & -20.55 & shell & AMS & 2.72 & $1190 \pm 30$ & $1640 \pm 40$ & $1191-925$ & IAAA-81004 & Marine09 & This study \\
\hline TA-1 & 46.35 & -42.35 & wood & AMS & -24.43 & $3130 \pm 30$ & $3140 \pm 30$ & $3444-3326$ & IAAA-41011 & IntCal09 & $\begin{array}{l}\text { Urabe et } \\
\text { al.(2006b) }\end{array}$ \\
\hline TA-1 & 60.12 & -56.12 & shell & AMS & -0.45 & $4100 \pm 40$ & $4490 \pm 40$ & $4701-4336$ & IAAA-41009 & Marine09 & $\begin{array}{l}\text { Urabe et } \\
\text { al.(2006b) }\end{array}$ \\
\hline TA-1 & 88.49 & -84.49 & shell & AMS & -4.18 & $9610 \pm 50$ & $9950 \pm 50$ & $10949-10538$ & IAAA-41014 & Marine09 & $\begin{array}{l}\text { Urabe et } \\
\text { al.(2006b) }\end{array}$ \\
\hline TA-1 & 91.06 & -87.06 & shell & AMS & -4.15 & $10360 \pm 50$ & $10700 \pm 50$ & $12061-11547$ & IAAA -41013 & Marine09 & $\begin{array}{l}\text { Urabe et } \\
\text { al.(2006b) }\end{array}$ \\
\hline$M Z-1$ & 18.38 & -17.68 & wood & AMS & -31.52 & $2900 \pm 40$ & $2800 \pm 40$ & $3000-2788$ & IAAA- 60083 & IntCal09 & This study \\
\hline$M Z-1$ & 29.90 & -29.20 & shell & AMS & -0.37 & $3120 \pm 40$ & $3520 \pm 40$ & 3390 & IAAA- 60084 & Marine09 & This study \\
\hline $\mathrm{SN}-1$ & 4.40 & -3.40 & wood & $\beta$ & -27.70 & $2070 \pm 100$ & $2030 \pm 110$ & 2211-1736 & IAA-959 & IntCal09 & Urabe(2008) \\
\hline $\mathrm{SN}-1$ & 21.20 & -2 & $\begin{array}{c}\text { peaty } \\
\text { fragment }\end{array}$ & AMS & 55 & $3920 \pm 40$ & $4140 \pm 40$ & $25-4568$ & IAAA-60087 & IntCal09 & Irabe(2008) \\
\hline $\mathrm{SN}-1$ & 28.74 & -27.74 & $\begin{array}{l}\text { peaty } \\
\text { fragment }\end{array}$ & AMS & -25.46 & $4460 \pm 40$ & $4450 \pm 40$ & $5144-4957$ & IAAA- 60088 & IntCal09 & Urabe(2008) \\
\hline $\mathrm{KN}-1$ & 6.27 & -5.47 & wood & AMS & -27.80 & $2960 \pm 30$ & $2910 \pm 30$ & $3162-2967$ & IAAA-81001 & IntCal09 & This study \\
\hline $\mathrm{KN}-1$ & 19.52 & -18.72 & $\begin{array}{l}\text { peaty } \\
\text { fragment }\end{array}$ & AMS & -27.50 & $4930 \pm 30$ & $4890 \pm 40$ & $5718-5584$ & IAAA-81002 & IntCal09 & This study \\
\hline
\end{tabular}

新たに掘削したコア試料とト部ほか（2006b）やト部 (2008) による 2 箇所のコア試料を用いた. 新規に掘削した コア試料は, 新潟市江南区早苗の新潟市立亀田西中学校敷地 内 $\left(\mathrm{N} 37^{\circ} 52^{\prime} 11^{\prime \prime}, \mathrm{E} 139^{\circ} 5^{\prime} 36^{\prime \prime}\right.$, 標高 $0.8 \mathrm{~m}$; 以下 KN-1 コ

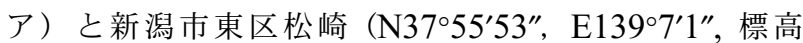
0.7 m；以下 MZ-1 コア）であり，再検討したコア試料は, 新潟市江南区中野山の SN-1 コア（ト部, 2008）と新潟市 東区太夫浜の TA-1 コア（ト部ほか, 2006b; 卜部, 2008） である (Fig. 2)，新規に掘削したコア試料は，半割し層相 や堆積構造などの記載を行った. その後, 新規掘削コアと再 検討コアの SN-1 は, $50 \mathrm{~cm}$ ごとに分析用試料を採取し, 再検討コアの TA-1 は $100 \mathrm{~cm}$ ごとに分析用試料を採取し た.

各試料は, $80^{\circ} \mathrm{C}$ で乾燥させたのち, 試料全体の重量を測 定してから 60，120，250 メッシュの篩で水洗した. その 後，それぞれの篩に残つたものを乾燥させ試料の重量を測定 し，各試料の粒度分布を求めた。

これらの試料のうち, 偏光顕微鏡によって粒径 $1 / 8$ $1 / 16 \mathrm{~mm}$ の鉱物組成, 重鉱物組成, 火山ガラスの形態を計 数した. 火山ガラスの形態は, 吉川（1976）の区分に従っ た. また，軽石片はコア試料の記載をする上で火砕物の指標 となり, 粒径 $1 / 4 \mathrm{~mm}$ 以上の試料に多く含まれることから, 実体顕微鏡によって粒径 $1 / 4 \mathrm{~mm}$ 以上の試料中の軽石片の 含有率を計数した.

年代測定は，すべて加速器分析研究所において AMS 法 や $\beta$ 線法を用いて測定した. TA-1 コアの一部と SN-1 コア の年代測定值は，すでにそれぞれ卜部ほか (2006b)， 卜部 （2008）で示している. 今回，これらと TA-1 コアで追加分 析した試料や MZ-1 コアと KN-1 コアで新たに測定した試 料を含めて, Calib 6.0.1 (Stuiver and Reimer, 1993) の 年代較正プログラムを用い, 炭質物試料は IntCal 09 (Re-
Table 2. Facies description and interpretation of cores, modified from Urabe (2008).

\begin{tabular}{c|l|l} 
Facies code & \multicolumn{1}{|c}{ Facies } & Sedimentary environment \\
\hline DL1 & $\begin{array}{l}\text { Cross-bedded very coarse sand to granule-grained gravel, } \\
\text { or medium to very coarse sand. Alternation of silt and thin } \\
\text { fine sand with thin peaty fragment bed or roottlet. }\end{array}$ & $\begin{array}{l}\text { Fluvial channel and flood } \\
\text { plain (delta plain) }\end{array}$ \\
\hline DL2 & $\begin{array}{l}\text { Medium to very coarse sand interbedded very fine sand to } \\
\text { muddy sand with small leben and bioturbation. }\end{array}$ & Delta front \\
\hline DL3 & $\begin{array}{l}\text { Muddy sand interbedded fine to very fine sand with small } \\
\text { leben and bioturbation. }\end{array}$ & Prodelta \\
\hline SF1 & $\begin{array}{l}\text { Parallel-laminated fine to medium sand. Muddy fine sand } \\
\text { with mud drape. }\end{array}$ & Backshore \\
\hline SF2 & Well-sorted medium to coarse sand with parallel lamination. & Foreshore \\
\hline SF3 & $\begin{array}{l}\text { Well-sorted medium to coarse sand with } \\
\text { trough cross-lamination. }\end{array}$ & Upper shoreface \\
\hline ES1 & $\begin{array}{l}\text { Alternation of cross-bedded coarse to very coarse sand and } \\
\text { silt to sandy silt. Silty deposit include peaty fragments. } \\
\text { Bioturbation. }\end{array}$ & Bay - head delta \\
\hline ES2 & $\begin{array}{l}\text { Sandy silt with thin fine to medium sand bed. Bioturbation. } \\
\text { Shells(brakish water) }\end{array}$ & Estuary (inner bay) \\
\hline ES3 & $\begin{array}{l}\text { Fine to very fine sand with thin muddy very fine sand. } \\
\text { Bioturbation. Shell fragment. }\end{array}$ & $\begin{array}{l}\text { Estuary (offshore side of } \\
\text { prodelta) }\end{array}$ \\
\hline ES4 & $\begin{array}{l}\text { Muddy fine to very fine sand with thin muddy sand. } \\
\text { Bioturbation. Shell fragment. }\end{array}$ & $\begin{array}{l}\text { Estuary } \\
\text { (sandy environment) }\end{array}$ \\
\hline ES5 & $\begin{array}{l}\text { Alternation of sandy sitt and muddy fine-to very fine sand. } \\
\text { Bioturbation. Shells(brakish water) }\end{array}$ & $\begin{array}{l}\text { Estuary } \\
\text { (muddy environment) }\end{array}$ \\
\hline ES6 & $\begin{array}{l}\text { Poor-sorted medium to coarse sand with gravel and shell } \\
\text { fragments. Erosion surface. }\end{array}$ & $\begin{array}{l}\text { Estuary (erosional shore } \\
\text {-face retreat) }\end{array}$ \\
\hline
\end{tabular}

imer et al., 2009), 貝片は Marine 09 (Reimer et al., 2009）の較正曲線を使用して較正年代を求めた（Table 1). なお, 貝片の年代較正では, Shishikura et al. (2007) に示 された 7 試料の $\Delta \mathrm{R}$ と $\Delta \mathrm{R}$ 䛊差を平均し, それぞれの值を 133 と 41 に仮定して用いた.

\section{ボーリングコア試料の層相および堆積環境}

越後平野の阿賀野川流域の沖積層の堆積システムは, 下位 よりエスチュアリーシステムからデルタシステムに変化する ことが明らかにされている（卜部, 2008)。ここでのデルタ システム相は, 堆積相 DL1 (デルタプレーン堆積物), 堆積 相 DL2（デルタフロント堆積物）および堆積相 DL3（プロ デル夕堆積物）からなり, デル夕前面域に発達する堆積相 SF3（上部外浜堆積物), 堆積相 SF2（前浜堆積物）と堆積 


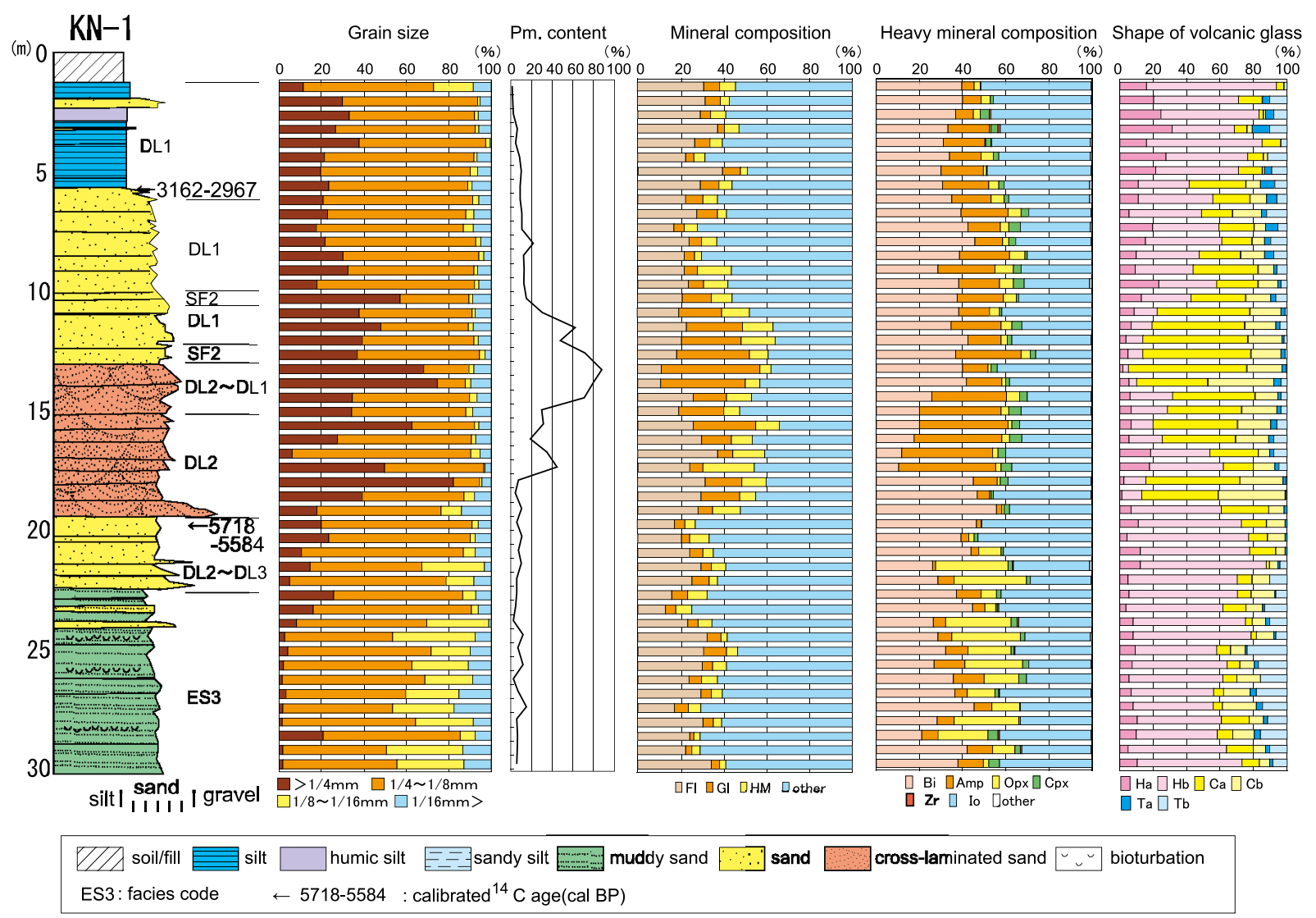

Fig. 3. Summary stratigraphic column of the $\mathrm{KN}-1$ core showing the facies, sedimentary facies codes, age in calibrated ${ }^{14} \mathrm{C}$ years (cal B.P.), grain size, pumice content, mineral composition, heavy mineral composition, and shape of volcanic glass. For detailed facies codes, see Table 2. Fl: feldspar; Gl: volcanic glass; HM: heavy minerals; Bi: biotite; Amp: amphibole; Opx: orthopyroxene; Cpx: clinopyroxene; $\mathrm{Zr}$ : zircon; Io: iron minerals; $\mathrm{Ha}, \mathrm{Hb}, \mathrm{Ca}, \mathrm{Cb}$, Ta, Tb: shape code of volcanic glass, after Yoshikawa (1976).

相 SF1（後浜堆積物）も含めている（Table 2)。また，エ スチュアリーシステム相は, 堆積相 ES1（湾頭デル夕堆積 物), 堆積相 ES2 (湾頭エスチュアリー堆積物), 堆積相 ES3 (砂質エスチュアリー堆積物), 堆積相 ES4 (エスチュ アリー堆積物）と堆積相 ES5（泥質エスチュアリー堆積物） から構成されている（Table 2).

本論では, 卜部（2008）により SN-1 コアと TA-1 コア の堆積相と堆積環境の変遷は明らかにされているため, 新規 に掘削した KN-1 と MZ-1 コアの記載を行い堆積環境や堆 積システムを認定した. なお，新規のコア掘削は，卜部 （2008）と同一地域内で行っているため, 堆積相の区分番号 (Table 2) は, 卜部（2008）と同じものを用いた. この結 果, 新規掘削のコアの層相は, おもにデルタシステム相とエ スチュアリーシステム相から構成されることが明らかとなつ た.

\section{KN-1 コア}

$\mathrm{KN}-1$ コアは, 掘進長 $30 \mathrm{~m}$, 口径 $66 \mathrm{~mm}$ でコアの回収 率はほぼ $100 \%$ であった（Figs. 2, 3)。深度 30.00〜 $22.19 \mathrm{~m}$ は, 主にやや淘汰の悪い細粒〜中粒の砂層からな る. 多くの生物擾乱や生痕化石が認められ，炭質物片を一部 に挟在する. 層相や生物擾乱から判断して, 堆積相 ES3 (砂
質エスチュアリー) に相当する. 深度 22.19〜19.55 m は, 主にやや淘汰の悪い細粒〜中粒の砂層からなり, 層厚数 $\mathrm{cm}$ $\sim 15 \mathrm{~cm}$ 程度の泥質砂層を挟在する. 細粒〜中粒の砂層に は斜交葉理がみられることがある. 泥質砂層には生物擾乱や 生痕化石が認められ, 下位層とは漸移的に重なる。 やや淘汰 の悪い砂層は河川起源を示唆し, 挟在される泥質砂層は浅海 での堆積環境を示す。これらは堆積相 DL2（デルタフロン ト)～堆積相 DL3（プロデル夕堆積物）に相当する. 深度 19.55 12.89 m は, 主に淘汰の悪い中粒〜極粗粒の砂層か らなり, 淘汰のよい細粒〜中砂の碟層を挟在する. 全体に中 粒〜細碟のサイズの軽石が含まれており, 軽石が濃集した層 も確認できる. 斜交葉理が発達する層準も挟在する. 碟の形 状は亜円〜円礫で, 礫層の基質は中〜粗粒砂であり生物擾乱 は認められない. 下位層とは漸移的に重なる. 層相や他の堆 積相との累重関係から, これらは堆積相 DL2（デルタフロ ント）～堆積相 DL1（デルタプレーン）に相当する.

深度 12.89〜5.92 m は, 主にやや塊状な細粒〜中粒の砂 層からなり炭質物片を含むことがある. このうち深度 12.89 〜 $12.17 \mathrm{~m}$ と深度 $11.0 \sim 10.0 \mathrm{~m}$ は, 淘汰がよく平行葉理 が認められる細粒〜中粒の砂層を挟在する. やや塊状な細粒 〜中粒の砂層は, 炭質物片を含むことから堆積相 DL1（デ 


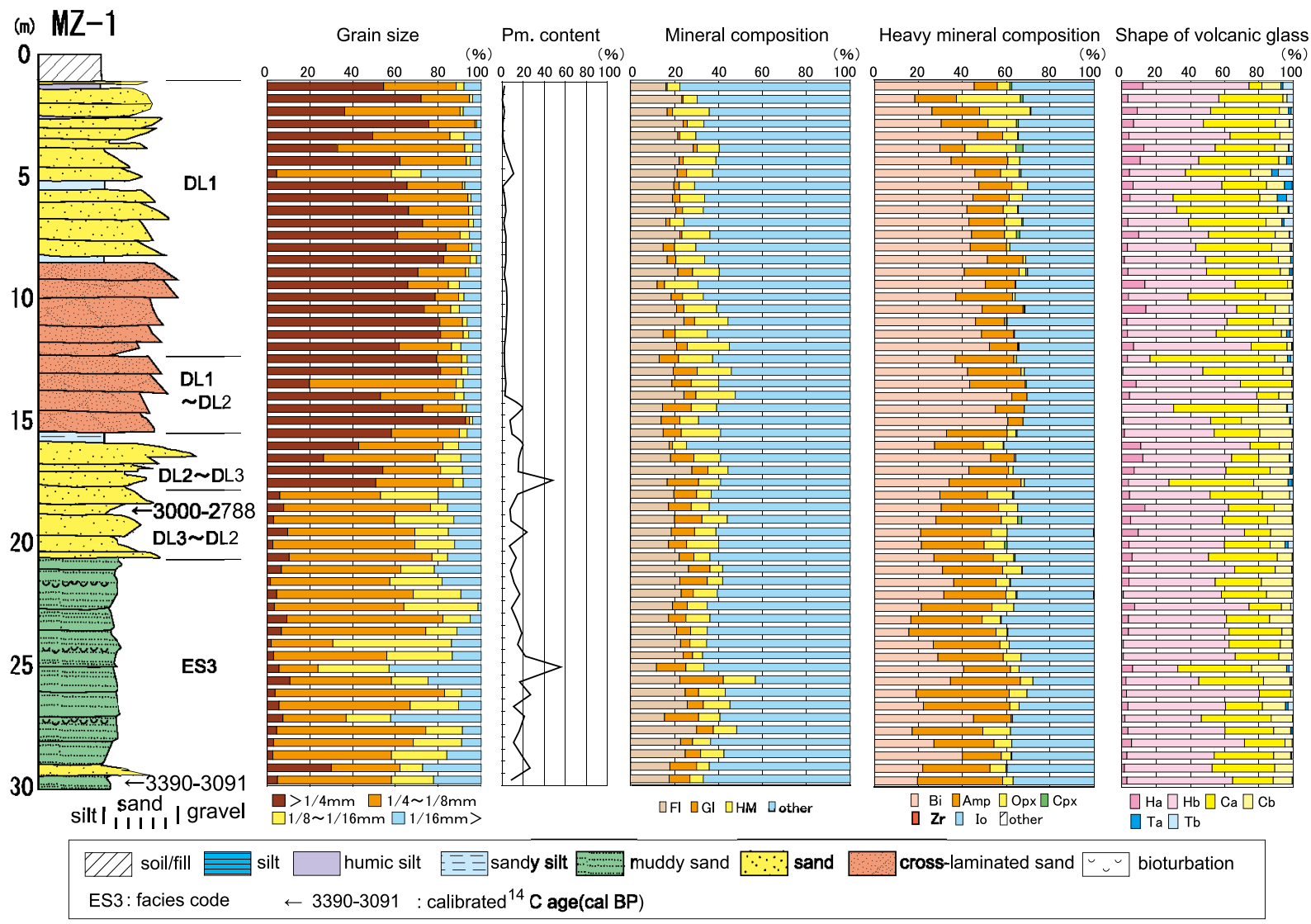

Fig. 4. Summary stratigraphic column of the MZ-1 core showing the facies, sedimentary facies codes, age in calibrated ${ }^{14} \mathrm{C}$ years (cal B.P.), grain size, pumice content, mineral composition, heavy mineral composition, and shape of volcanic glass. For detailed facies codes, see Table 2. As for Fig. 3, but for the MZ-1 core.

ルタプレーン）に相当する．また，挟在する淘汰がよく平行 葉理が認められる砂層は, 波浪の営力をうけているものと推 定できることから堆積相 SF2 に相当する. 全体ではデル夕 の堆積環境が推定される. 深度 5.92〜 $1.29 \mathrm{~m}$ は, 主に淘汰 のよいシルト〜シルト質極細粒砂層からなり，中粒〜粗粒砂 層を挟在する. 散在的に炭質物片を含夕生物擾乱は見られな い. 炭質物片を含有することや層相から判断して，これらは 堆積相 DL1（デルタプレーン）に相当し，河川の泥質な汇 濫原の堆積環境が推定される. 深度 $1.29 \sim 0.00 \mathrm{~m}$ は盛土で ある.

年代值は, 深度 $6.27 \mathrm{~m}$ で 3162 2967 cal BP, 深度 $19.52 \mathrm{~m}$ で 5718〜5584 cal BP を示す（Table 1).

\section{MZ-1 コア}

MZ-1 コアは, 掘進長 $30 \mathrm{~m}$, 口径 $66 \mathrm{~mm}$ でコアの回収 率はほぼ100\%であった（Figs. 2, 4)。深度 30.00〜 $20.51 \mathrm{~m}$ は, 主にやや淘汰の悪い細粒〜中粒の砂層で, シ ルト層や中〜粗粒サイズの軽石が濃集した薄層を挟在する. 生物擾乱，生痕化石が認められ，貝化石を含む．全体的に炭 質物片が散在する. 層相や生物擾乱, 貝化石の含有から判断 して, これらは堆積相 ES3（砂質エスチュアリー）に相当 する. 深度 $20.51 \sim 16.47 \mathrm{~m}$ は, 主に淘汰の悪い細粒〜中 粒の砂層で, 中粒〜粗粒砂層や生物擾乱を受けた砂質シルト
層を挟在する. 砂層には斜交葉理がみられることもある. 淘 汰の悪い砂層は河川の影響が強いことを示唆し, 挟在される 生物擾乱を受けた砂質シルトは浅海の堆積環境を示唆する. よって，これらは堆積相 DL3（プロデルタ）堆積相 DL2 （デルタフロント）に相当する. 深度 $16.47 \sim 8.54 \mathrm{~m}$ は, 主 に淘汰の悪い粗粒〜極粗粒の砂層で細〜中硯層を挟在する. 砂層には, 平行葉理が認められることがある. 細粒〜中碟層 の礫の形状は亜円〜円礫で下位層とは漸移的に重なる. 層相 から堆積相 DL2（デルタフロント）～堆積相 DL1（デルタ プレーン）に相当し，下位層準よりも全体に粗粒化している ことから, 河川要素の強い堆積環境が推定される. 深度 8.54 〜 $1.11 \mathrm{~m}$ は, 主に淘汰の悪い中粒〜粗粒の砂層である. 極 粗粒砂〜細砶層, 砂質シルト層を挟在する. 砂層は逆級化を 示すことがある. 逆級化を示す砂層は, 自然堤防などの河川 汇濫原の堆積環境が推定される（伊勢屋, 1982）. 全体の層 相から堆積相 DL1（デルタプレーン）に相当する. 深度 1.11〜0.00 m は盛土である.

年代值は, 深度 $18.38 \mathrm{~m}$ で 3000 2788 cal BP, 深度 $29.90 \mathrm{~m}$ で 3390〜3091 cal BP を示す（Table 1).

\section{各コア試料の粒度・構成鉱物の特徵}

新たに掘削した KN-1 コア，MZ-1 コアとト部（2008） 


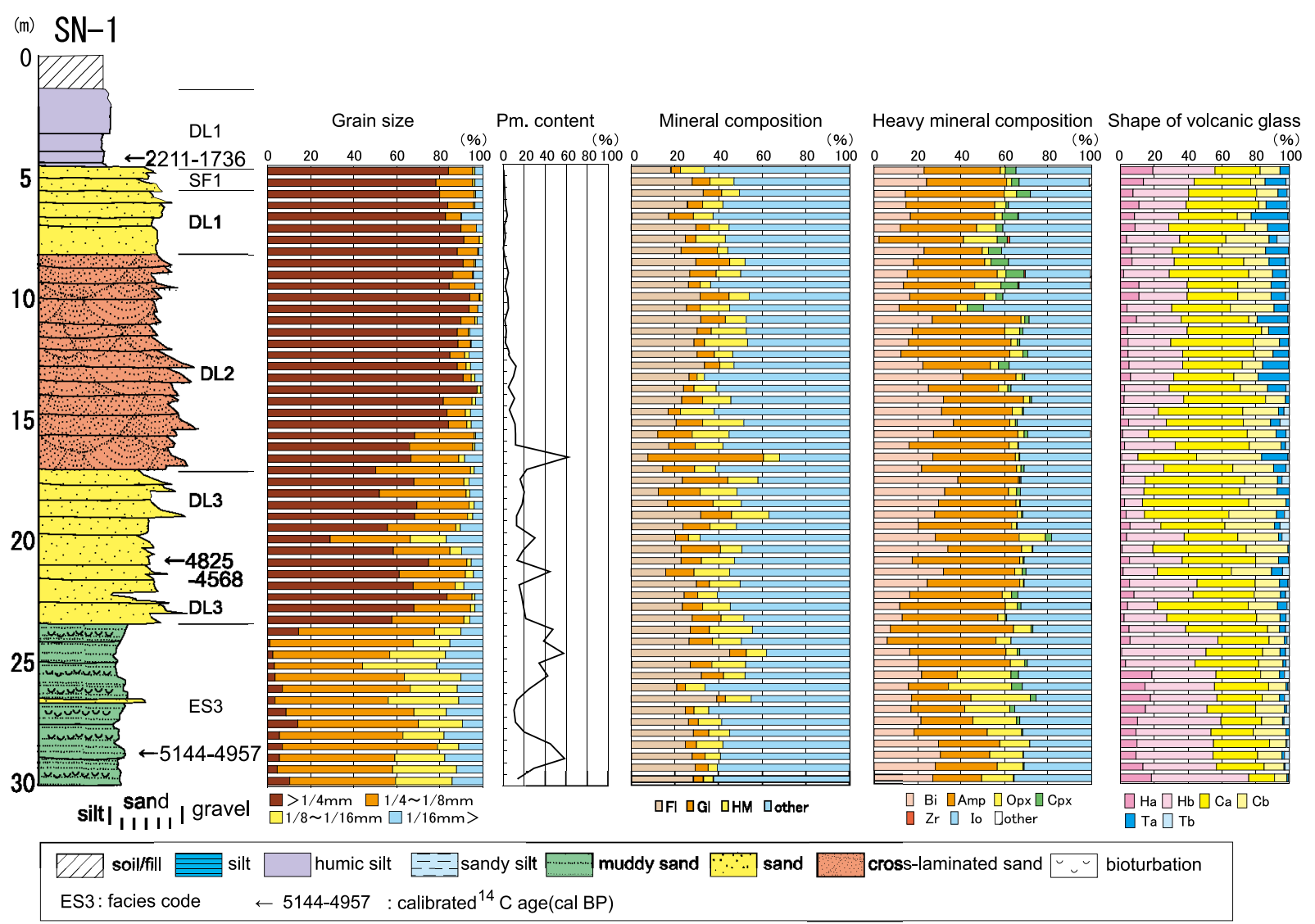

Fig. 5. Summary stratigraphic column of the SN-1 core showing the facies, sedimentary facies codes, age in calibrated ${ }^{14} \mathrm{C}$ years (cal B.P.), grain size, pumice content, mineral composition, heavy mineral composition, and shape of volcanic glass. For detailed facies codes, see Table 2. As for Fig. 3, but for the SN-1 core.

による SN-1 コア，TA-1 コアにおける粒度組成，粒径 $1 / 4 \mathrm{~mm}$ 以上での軽石の含有率，粒径 $1 / 8 \sim 1 / 16 \mathrm{~mm}$ の粒 子での鉱物組成, 重鉱物組成と火山ガラスの形態の特徵につ いて, 平野中央部から $\mathrm{KN}-1$ コア, $\mathrm{SN}-1$ コア, $\mathrm{MZ}-1$ コ ア, TA-1 コアの順に述べる.

\section{KN-1 コア}

深度 30.00 ２4.75 $\mathrm{m}$ では，粒径 1/8〜1/16 mm の粒子 が 20〜30\% 程度含まれる. 深度 $24.75 \sim 19.80 \mathrm{~m}$ では粒径 1/4 1/8 mm の粒子の割合が多い. 深度 $19.80 \sim 10.00 \mathrm{~m}$ では粒径 $1 / 4 \mathrm{~mm}$ 以上の粒子の割合が概ね約 $20 \sim 40 \%$ 以 上となる. 深度 $10.00 \sim 3.20 \mathrm{~m}$ では, 粒径 $1 / 4 \sim 1 / 8 \mathrm{~mm}$ の粒子が約 60〜 70\% 含まれる. 粒径 $1 / 4 \mathrm{~mm}$ 以上での軽 石の含有率は, 深度 $19.80 \sim 10.00 \mathrm{~m}$ で約 10〜80\% と多く 含まれ，粒径 $1 / 4 \mathrm{~mm}$ 以上の粒子を多く含む層準と一致す る (Fig. 3).

鉱物組成は，全体的に長石が約 10～35\% 含まれる. 重鉱 物は, 軽石が多く含まれる深度 19.80〜 10.00 m で約 10〜 $30 \%$ 含まれ，それ以外の層準では約 5〜15\% 含まれる. 火 山ガラスは, 深度 $10.00 \mathrm{~m}$ 以浅では約 5〜20\% 含まれ, 深 度 19.80 10.00 m の中で特に軽石が多く含まれる層準で は, 約 10〜 45\% を占める.

重鉱物組成は, 角閃石の含まれる割合の変化に特徵があ
る. 角閃石は, 深度 $30.00 \sim 18.83 \mathrm{~m}$ では約 $2 \sim 15 \%$ 含ま れるが, 深度 $18.83 \sim 3.15 \mathrm{~m}$ では約 10〜 55\% 含まれ, 特 に深度 $18.83 \sim 14.00 \mathrm{~m}$ では約 40〜 55\% 含まれる. 黒雲母 や鉄鉱物は, それぞれ全体の約 30〜 45\% を占める. 斜方輝 石は, 深度 $22.20 \mathrm{~m}$ 以深では全体の約 5 30\% を占めその 上位の層準では約 1〜13\% 含まれる. また, 単斜輝石は, 全体に約 1〜5\% 含まれている.

火山ガラスが多く含まれる深度 19.80〜10.00 m におけ る火山ガラスの形態は, 主に中間型であり約 20 60\% 含ま れる.

全体としては, 深度 19.80〜10.00 m の層準で粒径 1/4 mm 以上の粒子が多く含まれ，これらは主に軽石から構 成されている. また, この層準では, 火山ガラスと重鉱物の うち角閃石の含まれる割合が高い特徵がある.

\section{2. $\mathrm{SN}-1$}

深度 30.00 ～ $23.33 \mathrm{~m}$ では, 粒径 1/4〜 1/8 mm の粒子が 約 30〜 60\% 含まれる. 深度 $23.33 \sim 4.95 \mathrm{~m}$ では, 粒径 $1 / 4 \mathrm{~mm}$ 以上の粒子が多く含まれ, 深度 $23.33 \sim 14.83 \mathrm{~m}$ で は約 $50 \sim 80 \%$, 深度 $14.83 \mathrm{~m}$ より上位では約 $80 \%$ 以上含 まれている（Fig. 5).

粒径 $1 / 4 \mathrm{~mm}$ 以上での軽石の含有率は, 深度 29.00 $16.00 \mathrm{~m}$ で全体として約 15\% 以上となっており, 約 40〜 


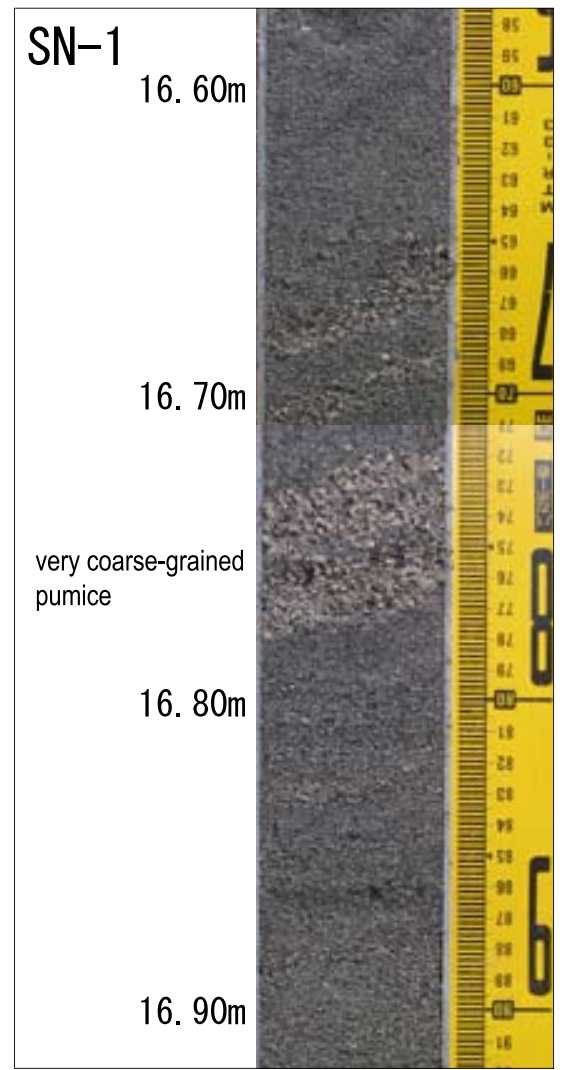

Fig. 6. Photograph of very coarse-grained pumice deposits with cross-laminations in the $\mathrm{SN}-1$ core (depth range, $16.57-16.92 \mathrm{~m})$. The pumice grains were derived from the Numazawako eruption $(\sim 5 \mathrm{ka})$.

$60 \%$ を示す層準もある. 粒径 $1 / 4 \mathrm{~mm}$ 以上の粒子の含有率 と合わせて考えると, 粒径 $1 / 4 \mathrm{~mm}$ 以上の粒子の含有率の 高い深度 23.33〜16.00 m において軽石の含有する絶対量 が多く, コア堆積物においても軽石の濃集が認められる (Fig. 6).

鉱物組成は，全体的に長石が約 5 45\% を占める。重鉱 物は，全体的に約 7〜 25\% を示す，火山ガラスは，深度 $23.33 \mathrm{~m}$ 以深では 5 15\% 程度含まれ, 軽石が多く含まれ る深度 23.33〜16.00 m において約 5２0\% 含まれる.

重鉱物組成は，KN-1 コアと同様に角閃石の含まれる割合 の変化に特徵がある．角閃石は，深度 $24.83 \mathrm{~m}$ 以浅におい て約 30〜 50\% 含まれ，これ以深では約 15〜25\% となる. 斜方輝石は，深度 $24.83 \mathrm{~m}$ 以浅において約 2〜10\%，これ 以深において約 10 25\% 含まれる. 単斜輝石は，全体的に 約 10\% 以下含まれる.

火山ガラスの形態は, 中間型の火山ガラスの含有量に特徵 があり, 深度 $24.83 \mathrm{~m}$ 以浅において約 40〜 60\% 含まれ, これ以深では約 $30 \%$ 以下となる。

全体としては, 粒径 $1 / 4 \mathrm{~mm}$ 以上の粒子が多く, 軽石の 含有量が多い層準で，中間型の火山ガラスと重鉱物のうち角 閃石の含まれる割合が高い特徵がある。

\section{MZ-1}

深度 $30.00 \sim 18.70 \mathrm{~m}$ では, 粒径 1/4 1/8 mm の粒子が 約 50〜 70\%, 粒径 1/8〜1/16 mm の粒子が概敉約 10〜30 $\%$ 含まれる. 深度 $18.70 \sim 5.70 \mathrm{~m}$ では, 粒径 $1 / 4 \mathrm{~mm}$ 以上 の粒子が約 60〜80\% 含まれる. 深度 5.70 0.70 m では, 粒径 $1 / 4 \mathrm{~mm}$ 以上の粒子が約 30 70\% 含まれる (Fig. 4).

粒径 $1 / 4 \mathrm{~mm}$ 以上での軽石の含有率は，深度 30.00 $14.00 \mathrm{~m}$ で全体として約 $10 \%$ 以上となっており，約 40〜 $55 \%$ を示す層準もある. 粒径 $1 / 4 \mathrm{~mm}$ 以上の粒子の含有率 と合わせて考えると, 粒径 $1 / 4 \mathrm{~mm}$ 以上の粒子の含有率の 高い深度 $17.00 \sim 14.00 \mathrm{~m}$ において軽石の絶対量が多い.

鉱物組成は，全体的に長石が 10〜25\%含まれる. 重鉱物 は，全体に約 5 20\% 含まれる，火山ガラスは，深度 30.0 $\sim 13.00 \mathrm{~m}$ では約 5 20\%, 深度 $13.00 \sim 8.70 \mathrm{~m}$ で 5\%, 深度 8.70 0.70 m で約 2 4\% 含まれる.

重釷物組成は, 角閃石が深度 $16.70 \mathrm{~m}$ 以深で約 20〜 $40 \%$ ，これ以浅では約 5 25\% 含まれる. 斜方輝石は, 深 度 $18.70 \mathrm{~m}$ 以深では約 5 10\%, 深度 $18.70 \sim 8.70 \mathrm{~m}$ では 約 5\% 以下となる. 単斜輝石は, 全体に約 5\% 以下である. 黒雲母は, 深度 $18.32 \mathrm{~m}$ 以深において約 20〜40\%, これ 以浅では約 $40 \sim 60 \%$ 含まれる. 火山ガラスの形態は, 深度 $18.70 \mathrm{~m}$ 以深で扁平型が約 50 60\% 含まれ，これ以浅では 中間型が約 40〜 60\% 以上と多く含まれる傾向がある.

前述の KN-1 コアや SN-1 コアでは，全体として粒径 $1 / 4 \mathrm{~mm}$ 以上の粒子が多い層準で，軽石，火山ガラスや角閃 石の含まれる割合が高い特徵があるが，MZ-1 コアでは， これらの傾向が顕著でない。

\section{TA-1}

深度 97.24 87.20 m では, 粒径 1/16 mm 以下の粒子が 約 65 95\% 含まれる. 深度 87.20 $85.20 \mathrm{~m}$ では粒径 1/8 $\sim 1 / 16 \mathrm{~mm}$ の粒子が約 $60 \%$ を占める. 深度 85.20 〜 $52.20 \mathrm{~m}$ では, 粒径 $1 / 16 \mathrm{~mm}$ 以下の粒子が約 65 95\% 含 まれる. 深度 $52.20 \sim 43.20 \mathrm{~m}$ では粒径 1/8〜 1/16 mm の 粒子が約 40〜 55\%, 粒径 1/16 mm 以下の粒子が約 30〜 $50 \%$ 含まれる. 深度 43.20 20.20 m では, 粒径 1/4〜 $1 / 8 \mathrm{~mm}$ が約 40 $60 \%$, 粒径 1/8 1/16 mm の粒子が約 20 40\% 含まれ, 粒径 1/4 1/8 mm の粒子の割合が増加 する. 深度 $20.20 \sim 12.20 \mathrm{~m}$ では粒径 $1 / 4 \mathrm{~mm}$ 以上の粒子 が約 30 80\%, 粒径 1/4 1/8 mm の粒子が約 30〜 60\% 含まれる. 深度 $12.20 \sim 0.20 \mathrm{~m}$ では粒径 $1 / 4 \mathrm{~mm}$ 以上の粒 子が約 60〜80\% 含まれる. 全体的に上方粗粒化の傾向を示 す (Fig. 7).

粒径 $1 / 4 \mathrm{~mm}$ 以上での軽石の含有率は, 深度 $58.20 \mathrm{~m}$ 以 深では概ね約 10\% 以下を示す. 深度 57.24〜 $20.20 \mathrm{~m}$ では, 全体的に約 15 40\% の值を示し, 約 40～60\% 以上含まれ る層準もある. 深度 $20.20 \sim 13.20 \mathrm{~m}$ では約 5 15\%, 深 度 $13.20 \sim 0.20 \mathrm{~m}$ では約 4\% 以下の割合を示す。

鉱物組成は，全体的に長石が約 10～40\% 含まれる，重鉱 物は，全体に約 10～20\% 含まれる，火山ガラスは，深度 $97.24 \sim 74.20 \mathrm{~m}$ では約 $15 \%$ 程度, 深度 $74.20 \sim 55.20 \mathrm{~m}$ では約 20\% 程度含まれる。深度 55.20〜 44.20 m では約 5 


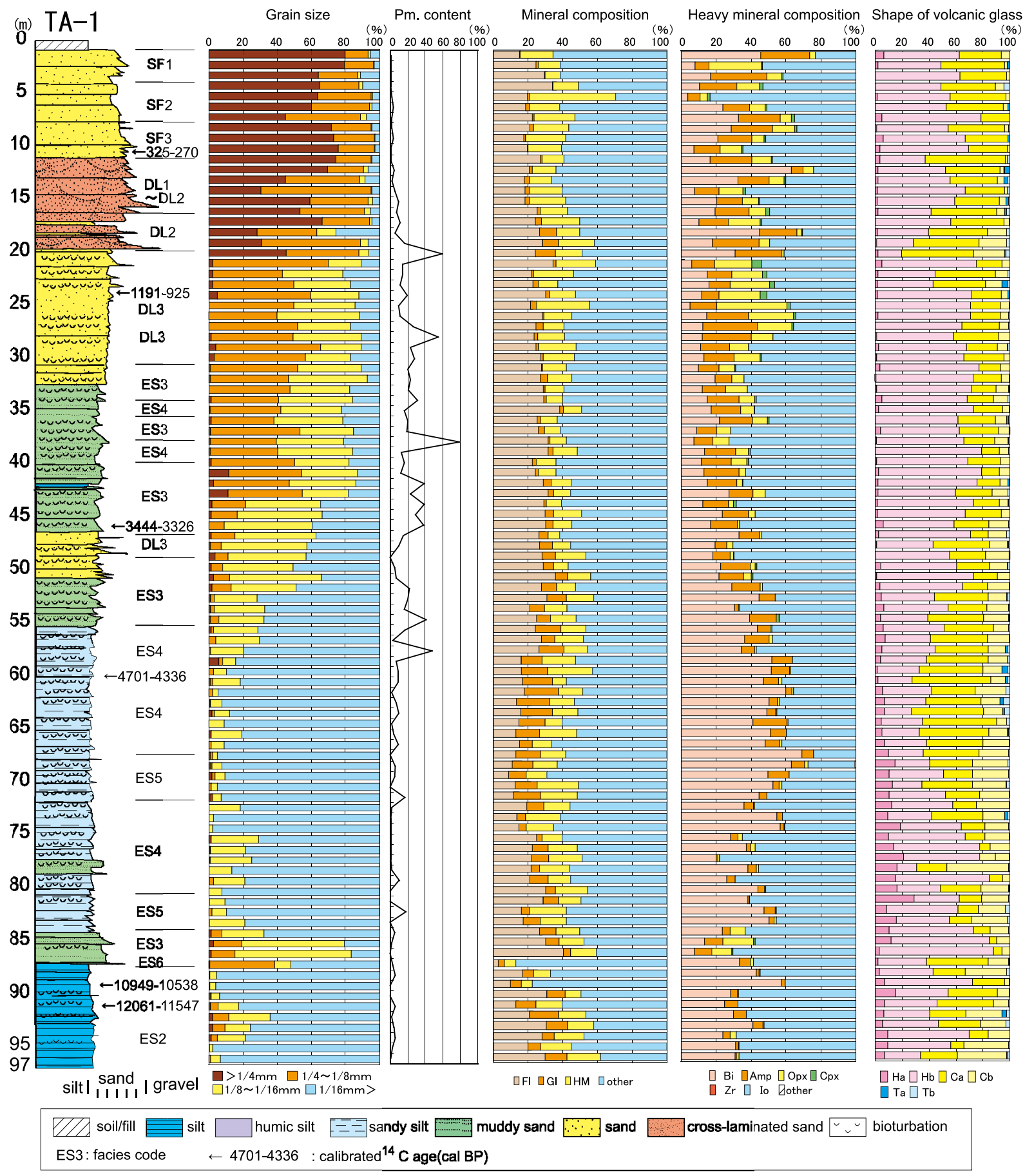

Fig. 7. Summary stratigraphic column of the TA-1 core showing the facies, sedimentary facies codes, age in calibrated ${ }^{14} \mathrm{C}$ years (cal B.P.), grain size, pumice content, mineral composition, heavy mineral composition, and shape of volcanic glass. For detailed facies codes, see Table 2. As for Fig. 3, but for the TA-1 core.

〜 10\% 含まれる. 深度 44.20〜0.20 m では約 1～5\% 含ま れ，このうち深度 19.34〜17.32 m では約 10\% 含まれる.

重鉱物組成は，黒雲母が深度 $75.20 \mathrm{~m}$ 以深では約 10〜 $50 \%$, 深度 75.20 51.20 m では約 30〜 65\% 含まれる. 深度 51.20 20.20 m では約 10〜20\%を示す。深度 $20.20 \mathrm{~m}$ 以浅では約 10〜 60\% の間で変化する. 角閃石は, 深度 $70.20 \mathrm{~m}$ 以深では約 5\% 以下で，これ以浅では約 10〜
35\% 含まれ上位の層準になるに従い増加する傾向を示す. 斜方輝石は, 深度 $44.20 \mathrm{~m}$ 以深では約 5\% 以下，これ以浅 では約 5〜15\% 含まれる. 単斜輝石は, 全体に約 5\% 以下 含まれる.

火山ガラスの形態は, 全体的に扁平型は約 40〜 70\%, 中 間型は約 20〜40\%含まれる.このうち深度 60.00〜 $70.00 \mathrm{~m}$ 付近の火山ガラスの多い層準や深度 19.34 




जे.

立. N

它擎

\&

ธึ?

牙

i

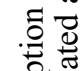

르을

용

党.

気

乙.

을

प⿺

苛

일

巳

웅

을

륭

可

tै.

ㅇํㅇ

㝵苛

递

:

כ)

을 융

픙

茄宁

范守

푱

60.8

皮家

की

월

要要

氙

is

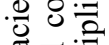

它

혿ㅎㅇ 
$19.30 \mathrm{~m}$ の軽石の濃集する層準では中間型が約 50〜 60\% 含 まれる.

TA-1 コアは, 阿賀野川河口域での沖積層のほぼ全層準を 採取しており，堆積環境の変遷に対応した粒度組成や重鉱物 組成の変化を示している.

\section{阿賀野川下流域における火砕物の二次堆積作用}

阿賀野川下流域の沖積層において, 沼沢火山起源の火砕物 の影響は, 沼沢湖噴火の火砕流堆積物を構成する粒子の特徵 である軽石, 角閃石, 火山ガラスの含有率によって示すこと ができる. Fig. 8 は，4本のボーリングコアの堆積相や軽石 の含有指標, 角閃石 - 火山ガラスの含有率の変化を示した. 軽石の含まれる割合の表現方法は, Figs. 3, 4, 5, 7 の各コ アでは粒径 $1 / 4 \mathrm{~mm}$ 以上の試料での含有率を示したが, 粒 度組成で粒径 $1 / 4 \mathrm{~mm}$ 以上の粒子の含有率が数 $\%$ 以下の場 合は，軽石の含有率が高率でも実際のコア試料にはほとんど 軽石が含まれず，含有率とコアの肉眼的な層相記載に差異が 生じる.このため, Fig. 8 では, コアを観察した際に軽石 が多い層準（粒径 $1 / 4 \mathrm{~mm}$ 以上の粒子の含有率が高く, か つ軽石の含有率も高い場合）を特徵づけるために，粒径 $1 / 4 \mathrm{~mm}$ 以上の粒子の含有率と軽石の含有率の積を軽石の含 有指標として設定し, 軽石の含まれる割合の表現方法とし た. また, 火山ガラス, 角閃石は, Figs. 3, 4, 5, 7 で示し た粒径 1/8〜1/16 mm の粒子での含有率を抜き出したもの である. 以下に示した各コアの軽石の含有指標, 火山ガラ ス, 角閃石の含有率 (Fig. 8) から, 火砕物の二次堆積作用 の開始層準の同定と堆積相と構成鉱物の特徵について述べ る.

\section{1. 二次堆積作用の開始層準と堆積相}

KN-1 コアでは, 深度 $19 \mathrm{~m}$ 層準の堆積相 DL2 の斜交層 理を伴う粗粒砂層の基底から, 軽石の含有指標, 粒径 $1 / 8$ $1 / 16 \mathrm{~mm}$ での火山ガラスと角閃石の含有率が増加する.こ の深度において二次堆積作用の影響を受けはじめたと考えら れる. 特に, 軽石の含有指標と火山ガラスの含有率は堆積相 DL2 の層準で多い. 年代值は, 深度 $19.52 \mathrm{~m}$ で 5718 $5584 \mathrm{cal} \mathrm{BP}$ 示し, 沼沢火山における沼沢湖噴火 （5340 cal BP）による決壊洪水イベントと調和的年代を示 す (Figs. 3, 8).

SN-1 コアでは, 軽石の含有指標は堆積相 DL3 の基底付 近の深度約 $23 \mathrm{~m}$ から増加する. 火山ガラスの含有率は, 深 度約 $25 \mathrm{~m}$ 層準から増加する傾向を示す. 角閃石の含有率は, 深度 $30 \mathrm{~m}$ において $20 \%$ を超えており KN-1 コアの基底付 近よりも高い傾向を示し, 特に, 深度約 $25 \mathrm{~m}$ 層準から増加 する. 深度 $28.74 \mathrm{~m}$ と $21.20 \mathrm{~m}$ の年代は，それぞれ 5144 〜4957 cal BP と 4825 4568 cal BP を示しており, 沼沢 湖噴火以降の時期を示す。深度 $30 \mathrm{~m}$ のコアの基底から角閃 石の含有率が高いことから, 堆積相 ES3 のエスチュアリー の堆積環境下においてすでに二次堆積作用の影響を受けはじ めていると考えられる. また, 洪水イベントによって浅海に もたらされた火砕物の影響が顕著になるのはデル夕の前進に 伴って層相がより粗粒化する層準からである (Figs. 5, 8).
MZ-1 では, 軽石の含有指標は堆積相 DL2 を示す深度約 18〜14 m 層準で増加する. 火山ガラスは, 深度 $30 \mathrm{~m}$ のコ ア基底から深度 $13 \mathrm{~m}$ 層準まで $10 \%$ 前後の含有率を示す. 角閃石は, 深度 $30 \mathrm{~m}$ のコア基底から深度 $13 \mathrm{~m}$ 程度までが 20 30\% 程度, これ以浅では $10 \%$ 前後の含有率を示す. 深度 $29.90 \mathrm{~m}$ と深度 $18.38 \mathrm{~m}$ の年代は，それぞれ 3390$3091 \mathrm{cal} \mathrm{BP}$ と 3000 2788 cal BP を示しており, 沼沢湖 噴火以降の時期を示す. 深度 $30 \mathrm{~m}$ のコアの基底から角閃石 の含有率が高いことから, 堆積相 ES3 のエスチュアリーの 堆積環境下で二次堆積作用の影響を受けはじめていると考え られる (Figs. 4, 8).

TA-1 では, 軽石の含有指標は堆積相 DL2 を示す深度約 21〜18 m 層準で増加し, 全体としてみるとその上位の堆積 相 DL1 の層準まで含有量が多い. 火山ガラスの含有率は, 深度約 $93 \mathrm{~m}$, 深度約 66 60 m と堆積相 DL2 を示す深度 約 21 $18 \mathrm{~m}$ 層準で増加している. 角閃石の含有率は, 深 度約 $70 \mathrm{~m}$ 層準以浅で $10 \%$ 前後となり, 深度約 $65 \mathrm{~m}$, 深 度約 $40 \mathrm{~m}$ 前後, 深度約 $30 \mathrm{~m}$ 以浅の層準で $20 \%$ 程度とな る.

年代は, 深度 $91.06 \mathrm{~m}$ で 12061 11547 cal BP, 深度 $88.49 \mathrm{~m}$ で $10949 \sim 10538 \mathrm{cal} \mathrm{BP}$, 深度 $60.12 \mathrm{~m}$ で 4701 〜 4336 cal BP, 深度 $46.35 \mathrm{~m}$ で 3444〜3326 cal BP を示 す. 沼沢火山における沼沢湖噴火の時期は, 年代值から深度 約 60〜88 m の間に相当する. 年代值を参考として, 火山 ガラスの含有率の高いピークを示す深度 $62.20 \sim 62.24 \mathrm{~m}$ 層準の火山ガラスの屈折率を温度変化型屈折率測定装置 （MAIOT: 古澤地質製）によって測定したところ， 1.4975 〜1.5062（モード 1.5015）を示した. 沼沢湖噴火の火砕流 堆積物に含まれる火山ガラスの屈折率は, $1.5000 \sim 1.5050$ を示すこと（町田・新井, 2003） から, 深度 62.20〜 $62.24 \mathrm{~m}$ 層準の火山ガラスの屈折率と一致する.このため, 深度約 66〜 60 m の火山ガラスの含有率の増加層準から沼 沢湖噴火の二次堆積作用の影響を受けている可能性が高い.

\section{2. 河川による火山砕屑物の過剩供給と堆積システムの前進}

二次堆積作用の開始時期の平野の古地理は, 現在の新潟市 亀田地域に分布する砂丘列群（新砂丘 I ）の前面に海岸線が 位置していたものと考えられている（Fig. 2: 田中ほか, 1996; Urabe et al., 2004; 鴨井ほか, 2006). また, 当時の 阿賀野川は, 現在の流路ではなく亀田地域の砂丘列群の南西 部に河口を有していたものと推定される（卜部, 2008).

内陸側の KN-1 コアは, 現在の亀田地域の砂丘列群北西 部に近接した地点で, 当時の阿賀野川の河口に近い浅海域の 位置にあると考えられる (Fig. 2). よって, KN-1 コアで は, 多量の軽石と火山ガラス, 角閃石などの火砕物が, 沼沢 湖噴火による火砕流によって堰き止められたダム湖の決壊に 起因した二次堆積物（決壊洪水堆積物）として運搬され, 沿 岸域でデル夕を形成したものと考えられる. また, 決壊洪水 流が平野域や KN-1 地点におよんだ際, より海側の地域 (SN-1, MZ-1, TA-1 コア) ではエスチュアリーの層相を示 す浅海が広がっていた.このため, これらの地域では, 浅海 域に運搬された火山ガラスと角閃石などの火砕物が堆積を開 
始する.

各コアの堆積相 DL2 の砂層には, 沼沢湖噴火に起因した 軽石が多く含まれ斜交層理を形成している特徵がある（Fig. 5).このうち, 陸地に近い KN-1 コアのデル夕の堆積相 (堆 積相 DL2）に含まれる軽石は，上述のように決壊起源の洪 水流で運ばれたものであるが，堆積年代から考慮すると SN-1, MZ-1, TA-1 コアの堆積相 DL2 の軽石粒は, 決壊 洪水个ベントにより浅海域にもたらされたものがデル夕前面 域での波浪営力により再運搬されて堆積したものと考えられ る.このように，砂層に多く含まれる軽石は，デル夕の前進 に伴って沖合方向に運搬されており，各地点での堆積には時 間差がある. KN-1 地点を決壊洪水イベントと同時に堆積し たデルタとすると，TA-1 地点までデルタが到達するには約 4000 年程度の差異がある.

このように沖積層の検討ならば時間分解能が高いことか ら, 約 $10 \mathrm{~km}$ 離れた KN-1 と TA-1 コアのデル夕堆積相の 対比で約 4000 年程度の差異があることがわかるが，時間分 解能が悪くなるより古い年代の地層では，これらの層相を 「斜交層理の発達する軽石を多く含夕同時間面の示標となる 鍵層」として対比してしまう可能性がある. 火砕物のうち特 に軽石の濃集した砂層を同時間面として対比する際には，軽 石を含む砂層の堆積相を検討した上で，時間分解能を考慮し た対比が必要となる.

また，デル夕の前進速度を，鴨井ほか（2006）などによ る各砂丘列の形成年代や本研究の検討結果から推定する. 決 壊洪水イベント以前では，亀田地域（Fig. 2）に分布する砂 丘列群（新砂丘 I-1 列から I-4 列）を例とすると，砂丘列が I-1 列の位置から I-4 列まで約 $1400 \mathrm{~m}$ 前進するのに約 1500 年を有していることから, 約 $0.9 \mathrm{~km} / 1000$ 年程度の 前進速度が見積もれる. しかし，決壊洪水イベント後では KN-1 コアから TA-1 コアまでのデル夕の前進速度を平均す ると約 $2.5 \mathrm{~km} / 1000$ 年程度となる. さらに，この洪水イべ ントの際の砂丘列（海岸線）の位置は亀田地域の砂丘列の北 限部分であるが, イベント後は, 新砂丘 I の位置から大きく 海側に前進し，SN-1 コアより北側の新砂丘 II の位置に移動 する (Fig. 2)．この新砂丘 I から新砂丘 II の砂丘列の急 速な前進やデル夕の前進速度の変化は，沼沢湖噴火による決 壊洪水イベントにより多量の火砕物が河川を通じて浅海域に もたらされたことに大きな影響を受けているものと考えられ る.これらは，火山起源の決壊洪水イベントが下流の平野部 にもたらす地形の変化や影響の継続時間などを推定していく 上で重要であり, 沖積平野（沖積層）の発達過程における土 砂供給イベントという側面のみならず，平野の上流部に位置 する火山において火山土砂災害が発生した際の影響範囲と被 害予測を行う上でも重要となる.

\section{ま と め}

本研究では, 越後平野の新潟市域の阿賀野川沿いにおいて 採集されたボーリングコア試料を用いて，各ボーリングコア 試料における粒度分布，鉱物組成，重鉱物組成，ガラス形態 について分析し沼沢湖噴火の二次堆積作用の影響について明
らかにした.

この結果, 内陸側の地域では, 軽石と火山ガラス, 重鉱物 （角閃石）などの火砕物が決壊イベントによる洪水流によっ て運搬されデル夕を形成することがわかった．また，海側の 地域では, 決壊イベントの発生時に, 沖合に運搬された大量 の軽石, 火山ガラス, 重鉱物（角閃石）などの火砕物が堆積 し，その後，デル夕の前進により軽石や火山ガラスを多く含 むデルタ相を示す砂層が広く分布した。

このような軽石の濃集した砂層は, 野外やコア試料の記載 の際には鍵層として着目されるが, 越後平野の沖積層の検討 では，デル夕の前進に伴い場所によって形成年代に大きな差 異があることがわかつた．軽石が濃集した砂層の鍵層として の対比は，砂層の形成過程を検討したうえで，時間分解能を 考慮し鍵層としての同時間性を検討する必要がある．また， このような平野における火砕物の二次堆積作用の研究は, 火 山噴火を起因とする大規模な土砂供給イベントが下流部の平 野の地形や地層の形成へ与える影響を評価するうえで重要で あり, 今後の火山活動による下流域での土砂災害の予測に役 立つことが考えられる.

\section{謝辞}

本研究は，日本学術振興会科学研究費補助金基盤研究 (A) (2) No.12301017（代表：新潟大学小林昌二), 同基盤研究 （C）（2）No.15540432（代表：新潟大学卜部厚志）と同基 盤研究 (C) (2) No.17540433（代表：新潟大学卜部厚志） の一部を使用した. ユタカボーリングの川島 豊氏にはボー リングの掘削に際しお世話になった. 甲賀地質研究所の安井

賢博士には，沖積層の層序や層相，コア試料の貝化石の同 定などについてご教示頂いた.これらの方々に記して謝意を 表します。

\section{引用 文 献}

伊勢屋ふじこ (Iseya, F.), 1982, 茨城県, 桜川における逆グレーディ ングをした洪水堆積物の成因. 地理評 (Geogr. Rev. Japan), 55, 597-613.

鴨井幸彦・安井 賢 - 小林耑雄 (Kamoi, Y., Yasui, S. and Kobayashi, I.), 2002, 越後平野中央部における沖積層層序の再検 討. 地球科学 (Earth Sci. (Chikyu Kagaku)), 56, 123-138.

鴨井幸彦 - 田中里志 - 安井 賢 (Kamoi, Y., Tanaka, S. and Yasui, K.), 2006, 越後平野における砂丘列の形成年代と発達史. 第四 紀研究 (Quatern. Res.), 45, 67-80.

片岡香子 - 卜部厚志 - 梶山敦司 (Kataoka, K., Urabe, A. and Kajiyama, A.), 2006, 二次堆積した火山砕屑物と地形から読み取れ る火山性大規模洪水流と火山性土砂災害. 月刊地球 (Chikyu Monthly), 28, 507-511.

Kataoka, K. S., Urabe, A., Manville, V. and Kajiyama, A., 2008, Breakout flood from an ignimbrite-dammed river after the 5 ka Numazawako eruption, northeast Japan. Geol. Soc. Amer. Bull., 120, 1233-1247.

Kataoka K. S., Manville, V., Nakajo, T. and Urabe, A., 2009, Impacts of explosive volcanism on distal alluvial sedimentation: Examples from the Pliocene-Holocene volcaniclastic successions of Japan. Sediment. Geol., 220, 306-317.

町田 洋・新井房夫 (Machida, H. and Arai, F.), 2003, 新編火山灰 アトラス：日本列島とその周辺 (Atlas of Tepra in and around Japan: Revised Edition). 東京大学出版会(Univ. Tokyo Press), 336p. 
新潟古砂丘グループ(Niigata Ancient Dune Research Group), 1974, 新潟砂丘と人類遺跡: 新潟砂丘の形成史 I . 第四紀研究 (Quatern. Res.), 13, 57-65.

新潟古砂丘グループ(Niigata Ancient Dune Research Group), 1979, 砂丘と平野. アーバンクボタ (Urban Kubota) , 17, 1215.

沼沢団体研究グループ(Numazawa Collaborative Research Group), 1999, 沼沢火山の地質と岩石. 地球科学(Earth Sci. (Chikyu Kagaku) ), 53, 53-70.

Reimer, P. J., Baillie, M. G. L., Bard, E., Bayliss, A., Beck, J. W., Blackwell, P. G., Bronk Ramsey, C., Buck, C. E., Burr, G. S., Edwards, R. L., Friedrich, M., Grootes, P. M., Guilderson, T. P., Hajdas, I., Heaton, T. J., Hogg, A. G., Hughen, K. A., Kaiser, K. F., Kromer, B., McCormac, F. G., Manning, S. W., Reimer, R. W., Richards, D. A., Southon, J. R., Talamo, S., Turney, C. S. M., van der Plicht, J. and Weyhenmeyer, C. E., 2009, IntCa109 and Marine09 radiocarbon age calibration curves, 0-50,000 years cal BP. Radiocarbon, 51, $1111-1150$

Shishikura, M., Echigo, T. and Kaneda, H., 2007, Marine reservoir correction for the central coast of Japan using ${ }^{14} \mathrm{C}$ ages pf marine mollusks uplifted during historical earthquakes. Quatern. Res., 67, 286-291.

Stuiver, M. and Reimer, P. J., 1993, Extended C-14 data- base and revised CALIB 3.0 C-14 age calibration program. $R a-$ diocarbon, 35, 215-230.

田中久夫 - 長谷川 正 - 木村澄枝 - 岡本郁栄 - 坂井陽一 (Tanaka, H., Hasegawa, T., Kimura, S., Okamoto, I. and Sakai, Y.), 1996, 新潟砂丘の形成史. 第四紀研究 (Quatern. Res.) , 35, 207 -218 .

坂井陽一(Sakai, Y.), 1980, 新潟砂丘における腐植層と砂丘砂の鉱物 組成: 新潟砂丘の形成について (その 1)。新潟県立教育センター 研究報告 (Bull. Niigata Pref. Educ. Center.), 49, 91-96.
卜部厚志 (Urabe, A.), 2008, 越後平野の阿賀野川沿いにおける沖積 層の堆積システム,第四紀研究 (Ouatern. Res.) , 47, 191-201.

卜部厚志・片岡香子(Urabe, A. and Kataoka, K.), 2005, 新潟平野 におけるイベント性堆積作用における堆積システムの変化. 日 本地質学会第 112 年学術大会講演要旨 (112th Ann. Meet. Geol. Soc. Japan, Abstr.), 107.

Urabe, A., Takahama, N. and Yabe, H., 2004, Identification and characterization of a subsided barrier island in the Holocene alluvial plain, Niigata, central Japan. Quatern. Intl., 115116, 93-104.

卜部厚志・吉田真見子・高濱信行 (Urabe, A., Yoshida, M. and Takahama, N.), 2006a, 越後平野の沖積層におけるバリアー: ラグーンシステムの発達様式. 地質論集 (Mem. Geol. Soc. Japan), 59, 111-127.

卜部厚志・安井 賢・稲葉 充・片岡香子・高濱信行 - 満田信一 (Urabe, A., Yasui, S., Inaba, M., Kataoka, K., Takahama, N. and Mitsuda, S.), 2006b, 東新潟ガス田の中部更新統〜完新統 の層序: 特に軽石層の特徵とその給源. 石技誌 (Jour. Japan. Assoc. Petrol. Tech.), 71, 337-348.

山元孝広 (Yamamoto, T.), 1995, 沼沢火山における火砕流噴火の多 様性: 沼沢湖および水沼火砕堆積物の層序, 火山 (Bull. Volcanol. Soc. Japan), 40, 67-81.

山元孝広 (Yamamoto, T.), 2003, 東北日本, 沼沢火山の形成史: 噴出 物層序, 噴出年代及びマグマ噴出量の再検討. 地調研究報告 (Bull. Geol. Surv. Japan), 54, 323-340.

山元孝広 ・駒沢正夫(Yamamoto, T. and Komazawa, T.), 2004, 宮 下地域の地質. 地域地質研究報告 (5 万分の 1 地質図幅) (Geology of the Miyashita District. Quadrangle Series, 1: $50,000)$. 産総研地質調査総合センター (Geol. Surv. Japan, AIST), 71p.

吉川周作 (Yoshikawa, S.), 1976, 大阪層群の火山灰層について. 地 質雑(Jour. Geol. Soc. Japan), 82, 479-515.

（要 旨）

卜部厚志・藤本裕介 - 片岡香子, 2011, 越後平野の沖積層形成における火山性洪水イベン

トの影響. 地質雑, 117, 483-494. (Urabe, A., Fujimoto, Y. and Kataoka, S. K., 2011, Influence of a volcanogenic flood event on an alluvial depositional system: the Holocene Echigo Plain of northeast Japan. Jour. Geol. Soc. Japan, 117, 483-494.)

越後平野は，日本海に面した沖積低地で複数の砂丘列が発達している. 平野部の阿賀野 川流域の沖積層において, 複数のボーリング試料の堆積相や構成鉱物の特徵から, 約 5000 年前の沼沢湖噴火によるラハール堆積物の堆積過程を検討した.

ラハールによる堆積物は, 当時の海岸部では層厚 5〜 $8 \mathrm{~m}$ 程度の軽石質なデルタを形成 した. また，決壊洪水イベントによる膨大な量の火砕物は，デルタシステムを急速に前進 させ海岸地形を変化させた.このような大規模な火砕物の再堆積作用の解明は, 平野の形 成過程における影響だけでなく，下流域での火山土砂災害としての予測につながる課題と なるものである. 